members of the Organization for Economic Cooperation and Development (OECD). Public spending in 1992-93, when the restructuring took place, accounted for 0.59 per cent of GDP; three years later, it had slipped to 0.52 per cent, compared with an OECD average of 0.69 per cent.

Simon Upton, Williamson's predecessor, committed the government to a target of increasing this to 0.8 per cent by 2010 . But Williamson says there has been "a loss of 'security of tenure' in our coalition government". And even Upton now admits that the prospects of a full government commitment to what he sees as an investment in the future "are in the balance".

Also under threat is another promise made by Upton that NZ\$30 million would be provided next year to the Marsden Fund, a scheme launched in 1994 that provides competitive grants for basic, non-targeted research in universities and CRIs.

Ross Moore, chief executive of the Royal Society of New Zealand, which administers the fund on behalf of the government, believes this goal is "in jeopardy". Indeed, with the value of the fund now standing at NZ\$22 million a year, and only one applicant in 13 being successful because of the fierce competition, any increase this year is unlikely to be more than NZ\$1 million. Sir John Scott, the society's president, describes the reduced funding as "a serious blow".

In a speech two months ago, Sir Ian Axford, who chairs the Marsden Fund, confirmed his support for the 1992 reforms, arguing they were necessary because the government had lost confidence in the former leaders of public research bodies.

But, while describing the system as "fairly reasonable", he argued that it was "ponderous and too concerned with process rather than purpose". Axford also criticized the policy of allowing science to be driven by market forces.

He also said the government must intervene to identify research priorities: "Unfortunately the level of our technology is rather low, and we desperately need to do something about it".

Scientists, said Axford, were now "too easily treated as seasonal workers who can be dropped and picked up on demand." Jobs were subject to individually tailored contracts, often limited by short-term grants.

One result is the difficulty for young scientists in establishing research careers, many having to settle for technician-grade posts that provide no chance of winning grants from the so-called Public Good Science Fund in competition with established scientists.

Megan Ogle-Mannering, for example, who holds a $\mathrm{PhD}$ in plant ecology from Otago University, recently left New Zealand after trying unsuccessfully for two years to find a post in which she might apply her training. She is now studying science com-

\title{
Government under fire from academics
}

To the disappointment of researchers, Maurice Williamson, New Zealand's Minister for Research, Science and Technology since 1996, has dropped the practice of his predecessor, Simon Upton, of consulting widely and directly with scientists, depending solely on policy advice from the 34 members of his ministry.

Where specific studies are needed, they are usually commissioned from the Royal Society of New Zealand under contracts worth NZ\$1.4 million this year. Established in an act of parliament, which was recently revised to extend its coverage from traditional to social and applied sciences, the society is officially independent of the government.

But maintaining its autonomous role is a delicate matter. In a celebrated spat starting in 1995, Philippa Black, a geologist and then president of the society, was declared persona non grata by Upton for criticizing the science system he championed (see Nature 379, 112 \& 380, 282; 1996).

Black says: "If anything my views have strengthened since then with the current strain on funding, including the impossible infrastructure position of PGSF, and

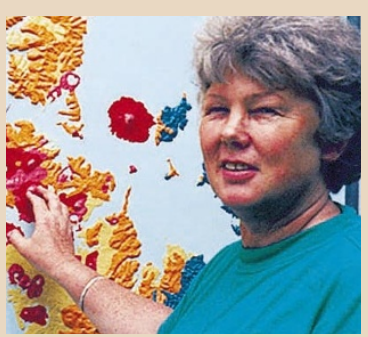

Black: critical of new system.

Marsden grants not allowing purchase of equipment costing more than $\$ 5,000$, and the high costs of managing research."

Sir John Scott, recently elected as the society's new president, describes the government's position on science as technically amounting to cuts, which he finds "very depressing". He says he runs the same risk as Black in describing the restructuring of the economy and science as "experimental and too dependent on accountants".

George Petersen, president of the academy council of the society and a biochemist at the University of Otago, says that one of the problems in New Zealand science is how to boost the morale of scientists, which he describes as being "at an alltime low", especially in universities.

He sees the 'technology foresight' process planned by

the government (see below) as not being properly linked to funding, educational and scientific workforce requirements.

In a joint statement, Scott and Petersen say they urgently need to lobby the government to influence longterm policy "without being continually knocked back with the response that scientists are just looking after their own interests".

The New Zealand Association of Scientists (NZAS) is less cautious. Its president, Brion Jarvis, a retired microbiologist, says he was elected because of his advocacy of science and his ability to comment freely, now that he is no longer bound to any organization.

Evenly split between universities and CRIs, the NZAS speaks for CRI staff who are prevented by their contracts from speaking publicly on policy issues.

Jarvis says there is a "groundswell of discontent" among CRI scientists and uncertainty over jobs. Indeed a US Fulbright scholar, Jack Sommer, found in 1995-96 that only a quarter of CRI researchers felt they could speak freely on public policy issues. Most said their job satisfaction has decreased in the past two years.

P.P.

munication in Australia.

A further problem is the continuing lack of investment in R\&D from the previously highly protected private industry sector. Those responsible for introducing the new system had promised initially that it would stimulate such investment. But it remains stubbornly low, standing at only 0.26 per cent of GDP in 1995-96; indeed, a survey last year found that expenditure declined from NZ\$248 million in 1993-94 to NZ\$240 million in the following year.

Williamson and the new prime minister, Jenny Shipley, have both acknowledged the urgent need for New Zealand's industry to become more competitive internationally, but are aware of the difficulties. Both place their hopes in a two-year consultative study of national goals and needs using the techniques of 'technology foresight' (see Nature 390, 651; 1997).
By using focus groups and media publicity, the government hopes to stimulate public enthusiasm for science, in the belief this will lead to an increased emphasis on research in both public and private investment and will help shift priorities within science to the needs of high-technology industries.

One important barrier to such a change in attitude appears to be the powerful Treasury, which remains opposed to government intervention. But government officials say they are optimistic about the new strategy.

Jill White, the Labour opposition spokeswoman for science, also says she welcomes the 'foresight' study but "only if the commitment to extended funding to reach the 2010 target is delivered". Williamson's statements, she says, appear to show that the government is "reneging with a weakening commitment to science".
PeterPockley 